\title{
Evaluating Chloropyrifos Induced Diabtes Mellitus, Pancreatic Toxic Effects in Adult Albino Rats and Whether This Insult Is Permanent or Temporary
}

\author{
Eman E. Khayal ${ }^{1}$ and Mona M. Ahmed ${ }^{2}$ \\ ${ }^{1}$ Forensic Medicine and Clinical Toxicology Department. \\ 2 Pathology Department. \\ Facultv of Medicine, Zagazig University, Egypt.
}

\begin{abstract}
Chlorpyrifos is one of the most commonly used organophosphorus insecticide. Many studies showed a relationship between pesticide exposure and occurrence of diabetes. The aim was to assess toxic effect of chloropyrifos on pancrease, its ability to induce diabetes mellitus in adult male rats and evaluate whether this toxic insult is permanent or temporary. Material and methods: 24 adult male albino rats were classified into four groups. Group I: negative control. Group II: positive control gavaged orally with $0.5 \mathrm{ml}$ of corn oil once a day for 8 weeks. Group III: gavaged orally with chlorpyrifos dissolved in corn oil $(6.75 \mathrm{mg} / \mathrm{Kg}$ b.w /day) for 8 weeks. Group IV: orally gavaged with chlorpyrifos by the same dose as group III for 8 weeks, then left without treatment for another 4 weeks. At the end of the study, body weight of all rats were measured then blood samples were taken from all rats to estimate serum levels of amylase, lipase, glucose, insulin, reduced glutathione (GSH) and malondialdehyde (MDA) levels. Then the pancreatic tissues were dissected and submitted to histopathological and ultra-structural examination. Results: chloropyrifos administration caused significant increases in serum amylase, lipase, glucose and MDA with also significant decreament in serum insulin and GSH. These biochemical changes were associated with hisopathological changes. Stoppage of exposure for 4 weeks caused partial to complete improvement. Conclusion: chloropyrifos had toxic effects on pancrease and was considered as a risk factor for diabetes mellitus and improvement could occur after stoppage of its exposure for a period.
\end{abstract}

Key words Organophophorus, Chloropyrifos, Pancrease, Glucose, Insulin

\section{Introduction}

$\mathrm{E}$ nvironmental pollution has a significant role in the occurrence of many diseases affecting humans, plants, and animals. One of the most important causes of environmental pollution is the excessive use of pesticides (Al-Haj et al., 2005).

Pesticides are group of substances used for prevention of undesired insects, rodents, plants, moss and other harmful organisms (Abdollahi et al., 2010). Because of inadequate enforcement of laws concerning pesticide use and inadequate financial resources, residual levels of pesticides in Egyptian foods are found to be higher than those discovered in the developed countries (Abdelaziz et al., 2010).

Organophosphorous compounds (OPs) are examples of pesticides that developed since 50 years ago and then they spread out over in agriculture (Garabrant et al ., 2009; Ghazala et al., 2013). Over the 90's period, they represented about $44 \%$ of the total amount of insecticides utilized in Egypt (Mansour, 2010). They inhibit acetylcholinesterase (AChE) with increasing acetylcholine levels in the cholinergic synapse. In addition to their cholinergic effects, OPs can induce oxidative stress (Soltaninejad and Abdollahi, 2009; Al-Shinnawy et al., 2014), that affects metabolic pathways (Karami-Mohajeri and Abdollahi, 2011), and causes hypoxia and inadequate tissue perfusion giving rise to different organs dysfunction (Kumar et al., 2010).

Chlorpyrifos(O,O-Diethyl

O-3,5,6trichloropyridin-2-pyridyl phosphorothioate) is one of the most commonly used OPs insecticide. It was first listed and marketed by Dow Chemical Company in 1965. It was used firstly to kill mosquitoes (Mitra, 2008; Mehta, 2009).

In agriculture, chlorpyrifos is extensively used in many crops such as cotton, corn, almonds, and fruit trees including oranges and apples (NASS, 2011). In addition, it is widely used as indoor pesticide in home, hotels, schools, hospitals and places of food industry (EPA, 2000). 
As a result of its excessive use, residues of chlorpyrifos have been found in the air (Cattani et al., 2001) and in the food (Sun et al., 2006; Randhawa et al., 2007) which had harmful effects on living organisms (Zhao et al., 2006).

Food and agriculture organization (FAO) and world health organization (WHO) classified chlorpyrifos as class II (moderately toxic) substance (FAO/WHO, 2000).

As OPs, chlorpyrifos, inhibits AChE with accumulation of acetylcholine in synaptic junctions leading to cholinergic toxicity (Kalender et al., 2012). It has also been found that repeated doses of chlorpyrifos caused significant dysfunction on different organs as liver (Sandhu et al., 2013), blood (Goel et al., 2006), immune system (Elelaimy et al., 2012), CNS (Diab et al., 2012), kidney (Mansour and Mossa, 2011) and thyroid gland (El-Sheikh and Ibrahim, 2017). It can also cause embryotoxicity, teratogenicity (Tian et al., 2005), and geneotoxicity (Sandhu et al., 2013).

Nowadays, there is a progressive increase in the incidence of diabetes mellitus (Shrestha et al., 2016). Diabetes mellitus (DM) is a chronic disorder identified by systemic hyperglycemia that results from disturbance in action or secretion of insulin or both. Type 2 DM is a disease caused and affected by many factors involving environmental and occupational factors (Gangemi et al., 2016).

There were studies showed a relationship between pesticide exposure and occurrence of insulin resistance diabetes (Cox et al., 2007; Raafat et al., 2012). So, the aim of this study was to assess toxic effect of chloropyrifos on pancrease, its ability to induce diabetes mellitus in adult male albino rats and evaluate the persistence of these effects.

\section{Material \& Methods Chemicals}

Chlorpyrifos: It was bought as a powder from Sigma-

Aldrich, Germany imported by Cairo Chemical

Company.

Corn oil: It was obtained in the form of oily solution as solvent agent.

\section{Experimental animals and design}

Twenty four adult male albino rats (200-210 gm in weight) were obtained from the animal breeding house of Faculty of Medicine, Zagazig University. The animals were put in suitable cages and supplied with commercial laboratory animal food and water. According to "Guide for the Care and Use of Laboratory Animals", all animals received care in compliance with animal care guidelines and ethical regulations (ILAR, 1996). The animals were equally divided into 4 groups as following: negative control group (I): 6 rats received only regular diet and water to determine the basic values of performed tests for 8 weeks. Positive control group (II): 6 rats gavaged orally with $0.5 \mathrm{ml}$ of corn oil once daily for 8 weeks. Chloropyrifos group (III): 6 rats gavaged orally with chlorpyrifos dissolved in corn oil $(6.75 \mathrm{mg} / \mathrm{Kg} \mathrm{b.w}$ /day) for 8 weeks. This dose represented 1/20 of oral LD50 (135 mg/kg) (Goel et al., 2005). Follow up group (IV): 6 rats orally gavaged with chlorpyrifos by the same dose as group III for 8 weeks, and then they were left without treatment for another 4 weeks.

A day after the last dose of treatments, body weight of all rats were measured then venous blood samples were taken from the retro-orbital plexus by means of capillary glass tubes according to a method described by Joslin (2009) from all rats of all groups. The blood samples were left to coagulate then centrifuged to separate the serum. The sera were maintained at $\left(-20^{\circ} \mathrm{C}\right)$ to be used for estimating serum levels of amylase enzyme, lipase enzyme, glucose, insulin, reduced glutathione (GSH) and malondialdehyde (MDA) levels. Then the anesthetized animals were sacrificed and pancreatic tissues were dissected and submitted to histopathological and ultrastructural examination.

Methods

\section{Biochemical examination:}

- Lipase and amylase serum levels were measured by enzymatic colorimetric test by following the method of Lott et al. (1986) and Kurahashi and Inomata (1988) respectively.

- Serum insulin was determind by enzymelinked immunosorbant assay (ELISA) according to the method of Carlsson et al. (2010).

- Serum glucose was assayed colorimetrically according to the method of Trinder (1969).

- Spectrophotometric assay was used to determine the serum activities of MDA and GSH according to the methods described by Yoshioka et al. (1979) \& Beutler et al. (1963) respectively.

\section{Histopathological examination}

A portion of pancrease was fixed in $10 \%$ formalin saline, then embedded in paraffin blocks and processed for the preparation of $5 \mu \mathrm{M}$ thickness sections. These sections were stained by hematoxylin and eosin stains following the method described by Bancroft and Steven (1996) and examined by light microscopy.

\section{Ultra-structurral examination}

Another portion of pancrease were fixed in $2.5 \%$ solution of glutaraldehyde and then post fixed in $1 \%$ osmium tetra oxide dissolved in the same buffer. Then samples were dehydrated in graded ethanol alcohol, and then embedded in epoxy resin. $0.5-1 \mu \mathrm{m}$ semi- thin sections were stained with $1 \%$ toluidine blue and examined and photographed by light microscopy. Ultrathin sections $(70-90 \mathrm{~nm})$ were cut and stained with uranyl acetate and lead citrate (Glauret and Lewis, 1998) and examined by Electron Microscope, Faculty of Agriculture, Mansoura University.

All data were collected and subjected to be statistically analyzed by using SPSS Software program. ANOVA (F) test followed by least significant difference test (LSD test) \& Pearson correlation (r) were performed. $\mathrm{P}$ value $<0.05$ was considered to be significant.

\section{Result}

No statistically significant differences were found between negative and positive control groups as regard body weight and biochemical parameter $(\mathrm{p}>0.05)$ 
(Figure 1), so that negative control group was used for comparison with other groups.

\section{Body weight}

There was a highly significant reduction in body weight gain in chloropyrifos group when compared to control group. Stoppage of chloropyrifos exposure for 4 weeks caused significant increase in body weight, but still lower than that of control group (Table 1).

\section{Biochemical parameters}

\section{1- Serum amylase and lipase enzymes.}

Chloropyrifos administration for 8 weeks induced significant increases in serum amylase and serum lipase mean values comparing with that of negative control group. Stoppage of chloropyrifos exposure for 4 weeks caused partial improvement in these pancreatic enzymes (Table 2).

\section{2- Serum glucose and serum insulin.}

By ANOVA test, there were significant differences between control group, chloropyrifos group, and follow up group as regard serum glucose and serum insulin mean values. By using LSD test, there was a significant elevation in serum glucose with significant decrement in serum insulin in chloropyrifos group compared to negative control group. After 4 weeks of exposure stoppage, there were partial to complete reversal in serum glucose and insulin levels (Table 3).

\section{3- Serum MDA and GSH.}

There were highly significant elevation in the mean values of MDA and highly significant decrement in the mean values of GSH in chloropyrifos group compared to that of negative control one. Partial to complete reversal in these parameters was occurred after cessation of chloropyrifos exposure for 4 weeks (Table 4).

Pancreatic enzymes (serum amylase and serum lipase) were positively correlated with lipid peroxidation marker (serum MDA) and negatively correlated with serum GSH. Also, serum glucose was positively correlation with serum MDA, negatively correlated with serum GSH. It was also found that serum insulin was negatively correlated with lipid peroxidation marker (serum MDA) and positively correlated with serum GSH (Table 5).

\section{Histopathological and ultra-structural examination}

Light microscopically examination of pancrease in control groups showed normal pancreatic structure in the form of normal islets of Langerhans surrounded by the pancreatic acini with normal interlobular connective tissue (Figs 2A, 2B). While, pancreatic sections from chloropyrifos group displayed degeneration of cells of acini with widening of the interlobular spaces with blood vessels and infiltrated by inflammatory cells. Cells of islet of Langerhans are degenerated (Fig 2C). Cessation of chloropyrifos administration for another 4 weeks caused clear improvement in the histopathological alterations as there was no inflammatory reaction, only mild degeneration of acinar cells. Cells of islet of Langerhans showed mild degenerative change and still widening of intercellular septa (Fig 2D).

By examining ultra-structure of pancreatic acini of ultrathin sections of the pancreas obtained from control groups showed pyramidal acinar cells, with rounded basal nuclei containing prominent nucleoli. The cytoplasm was full of cisternae of rough endoplasmic reticulum and many secretory granules. Small amounts of connective tissue surround these acini (Figs 3A, 3B).

Chloropyrifos administration for 8 weeks caused shrunken acinar cells with heterochromatic nuclei and electron dense cytoplasm containing many vacuoles. The interstitial connective tissue appeared widening with macrophage (Fig 3C). Obvious improvement in these changes was displayed after discontinuation of chloropyrifos use for 4 weeks (Fig 3D).

Table (1): ANOVA one way and LSD statistical analysis of mean values of body weight (gm) among different studied groups.

\begin{tabular}{|c|c|c|c|c|c|}
\hline & $\begin{array}{c}\text { Negative control } \\
\text { group (I) } \\
\text { Mean } \pm \text { SD }\end{array}$ & $\begin{array}{c}\text { Chloropyrifos } \\
\text { group ( III ) } \\
\text { Mean } \pm \text { SD }\end{array}$ & $\begin{array}{c}\text { Follow up Group } \\
\text { (IV) } \\
\text { Mean } \pm \text { SD }\end{array}$ & F & P \\
\hline Body weight (gm) & $227.27 \pm 4.1$ & $184.03 \pm 3.31 \mathbf{a}$ & $214.7 \pm 2.49$ a b & 261.14 & $<0.0001 *$ \\
\hline
\end{tabular}

$S D=$ Standard Deviation, Number of rats $=6$ rats for each group, gm $=$ gram, $\boldsymbol{a}=$ highly significant difference as compared to control group $(P<0.001), \boldsymbol{b}=$ highly significant difference as compared to chloropyrifos group $(P<$ 0.001).

Table (2): ANOVA one way and LSD statistical analysis of mean values of serum amylase (U/L) and lipase (U/L) enzymes among different studied groups.

\begin{tabular}{|c|c|c|c|c|c|}
\hline & $\begin{array}{c}\text {-ve Control group } \\
\text { (I) } \\
\text { Mean } \pm \text { SD }\end{array}$ & $\begin{array}{c}\text { Chloropyrifos group ( } \\
\text { III ) } \\
\text { Mean } \pm \text { SD }\end{array}$ & $\begin{array}{c}\text { Follow up Group } \\
\text { (IV) } \\
\text { Mean } \pm \text { SD }\end{array}$ & F & P \\
\hline $\begin{array}{c}\text { Serum amylase } \\
\text { (U/L) }\end{array}$ & $118.95 \pm 0.35$ & $297.91 \pm 4.5$ a & $159.5 \pm 6.67$ a b & 2444.49 & $<0.0001^{*}$ \\
\hline Serum lipase (U/L) & $30.29 \pm 1.35$ & $70.14 \pm 2.25$ a & $45.93 \pm 2.66$ a b & 518.37 & $<0.0001^{*}$ \\
\hline
\end{tabular}

$S D=$ Standard Deviation, Number of rats $=6$ rats for each group, $U / L=$ units per liter, a $=$ highly significant difference as compared to control group $(P<0.001), \boldsymbol{b}=$ highly significant difference as compared to chloropyrifos group $(P<0.001)$. 
Table (3): ANOVA one way and LSD statistical analysis of mean values of serum glucose (mg/dl) and insulin (m IU/ml) enzymes among different studied groups.

\begin{tabular}{|c|c|c|c|c|c|}
\hline & $\begin{array}{c}\text {-ve Control } \\
\text { group (I) } \\
\text { Mean } \pm \text { SD }\end{array}$ & $\begin{array}{c}\text { Chloropyrifos } \\
\text { group ( III ) } \\
\text { Mean } \pm \text { SD }\end{array}$ & $\begin{array}{c}\text { Follow up Group } \\
\text { (IV) } \\
\text { Mean } \pm \text { SD }\end{array}$ & F & P \\
\hline Serum glucose (mg/dl) & $116.17 \pm 0.73$ & $267.93 \pm 5.75$ a & $149.56 \pm 3.83 a b$ & 2371.56 & $<0.0001^{*}$ \\
\hline Serum insulin (mIU/ml) & $2.48 \pm 0.02$ & $1.68 \pm 0.026$ a & $2.52 \pm 0.04$ b & 1398.74 & $<0.0001^{*}$ \\
\hline
\end{tabular}

$S D=$ Standard Deviation, Number of rats $=6$ rats for each group, $\mathrm{mg} / \mathrm{dl}=$ milligram per deciliter $\mathrm{m} \mathrm{IU} / \mathrm{ml}=\mathrm{milli}$ international Units per milliliter, $\boldsymbol{a}=$ highly significant difference as compared to control group $(P<0.001), \boldsymbol{b}=$ highly significant difference as compared to chloropyrifos group $(P<0.001)$.

Table (4): ANOVA one way and LSD statistical analysis of mean values of serum MDA(nmol/L) and GSH (nmol/L) enzymes among different studied groups.

\begin{tabular}{|c|c|c|c|c|c|}
\hline & $\begin{array}{c}\text {-ve Control } \\
\text { group (I) } \\
\text { Mean } \pm \text { SD }\end{array}$ & $\begin{array}{c}\text { Chloropyrifos } \\
\text { group ( III ) } \\
\text { Mean } \pm \text { SD }\end{array}$ & $\begin{array}{c}\text { Follow up Group } \\
\text { (IV) } \\
\text { Mean } \pm \text { SD }\end{array}$ & F & P \\
\hline MDA(nmol/L) & $0.42 \pm 0.06$ & $2.09 \pm 0.26$ a & $0.49 \pm 0.07$ b & 202.37 & $<0.0001^{*}$ \\
\hline GSH(nmol/L) & $1.37 \pm 0.997$ & $0.57 \pm 0.076$ a & $1.02 \pm 0.075$ a b & 136.19 & $<0.0001^{*}$ \\
\hline
\end{tabular}

$S D=$ Standard Deviation ,Number of rats $=6$ rats for each group, $\mathrm{nmol} / \mathrm{L}=$ nanomoles per liter, MDA= malondialdehyde, GSH =reduced glutathione, $\boldsymbol{a}=$ highly significant difference as compared to control group (P $<$ 0.001), $\boldsymbol{b}=$ highly significant difference as compared to chloropyrifos group $(P<0.001)$.

Table (5): Correlation between oxidative stress markers (MDA, GSH), pancreatic enzymes (serum lipase, serum amylase), serum glucose, and serum insulin.

\begin{tabular}{|c|c|c|c|c|c|c|c|c|c|c|}
\hline \multirow[t]{2}{*}{ Parameter } & \multicolumn{2}{|c|}{ Lipase (U/L) } & \multicolumn{2}{|c|}{ Amylase (U/L) } & \multicolumn{2}{|c|}{$\begin{array}{l}\text { Serum glucose } \\
\text { (mg/dl) }\end{array}$} & \multicolumn{2}{|c|}{$\begin{array}{l}\text { Serum insulin(m } \\
\text { IU/ml) }\end{array}$} & \multicolumn{2}{|c|}{ GSH(nmol/L) } \\
\hline & $r$ & p.value & $r$ & p.value & $r$ & p.value & $r$ & p.value & $r$ & p.value \\
\hline Amylase(U/L) & 0.981 & $<0.001 * *$ & & & 0.997 & $<0.001^{* *}$ & $\begin{array}{c}- \\
0.967\end{array}$ & $<0.001^{* *}$ & $\begin{array}{c}- \\
0.959\end{array}$ & $<0.001^{* *}$ \\
\hline $\begin{array}{c}\text { Serum glucose } \\
(\mathrm{mg} / \mathrm{dl})\end{array}$ & 0.978 & $<0.001^{* *}$ & 0.997 & $<0.001^{* *}$ & & & $\begin{array}{c}- \\
0.969\end{array}$ & $<0.001^{* *}$ & $\begin{array}{c}- \\
0.957\end{array}$ & $<0.001^{* *}$ \\
\hline $\begin{array}{c}\text { Serum } \\
\text { insulin }(\mathrm{mIU} / \mathrm{ml})\end{array}$ & $\begin{array}{c}- \\
0.91\end{array}$ & $<0.001 * *$ & $\begin{array}{c}- \\
0.967\end{array}$ & $<0.001^{* *}$ & $\begin{array}{c}- \\
0.969\end{array}$ & $<0.001 * *$ & & & 0.877 & $<0.001^{* *}$ \\
\hline GSH(nmol/L) & $\begin{array}{c}- \\
0.975\end{array}$ & $<0.001^{* *}$ & $\begin{array}{c}- \\
0.959\end{array}$ & $<0.001^{* *}$ & $\begin{array}{c}- \\
0.957\end{array}$ & $<0.001 * *$ & 0.877 & $<0.001^{* *}$ & & \\
\hline MDA(nmol/L) & 0.917 & $<0.001 * *$ & 0.967 & $<0.001^{* *}$ & 0.969 & $<0.001^{* *}$ & $\begin{array}{c}- \\
0.977\end{array}$ & $<0.001^{* *}$ & $\begin{array}{c}- \\
0.891\end{array}$ & $<0.001^{* *}$ \\
\hline
\end{tabular}

$r$ : Pearson correlation, ${ }^{*}$ Highly Significant $(P<0.001), U / L=$ units per liter, $\mathrm{mg} / \mathrm{dl}=$ milligram per deciliter,$m$ $I U / m l=$ milli international Units per milliliter, $n m o l / L=$ nanomoles per liter,$M D A=$ malondialdehyde, GSH $=r e d u c e d$ glutathione.
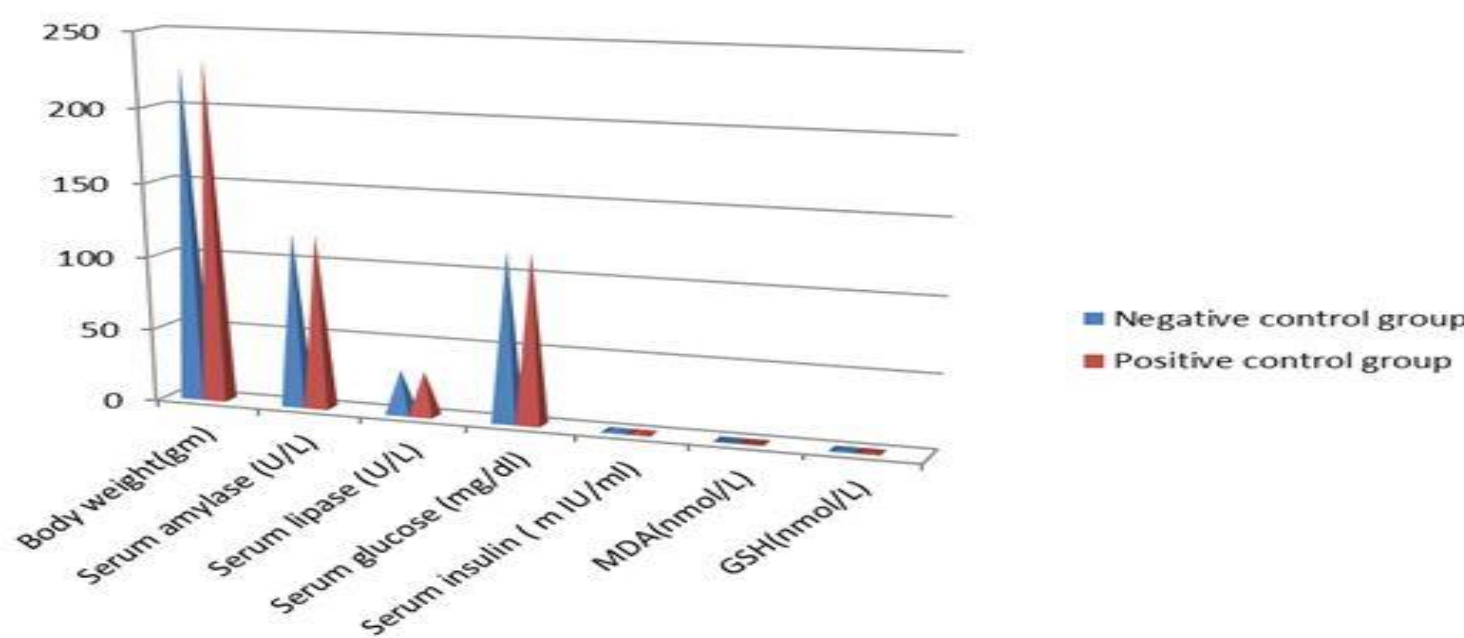

Figure 1: Bar chart showing comparison between negative control group and positive control group as body weight and mean values of serum amylase, serum lipase, serum glucose, serum insulin, serum MDA, and serum GSH levels. Values obtained from rats treated for 8 weeks.

Data expressed as Mean \pm SD (Number $=6$ rats/group). 


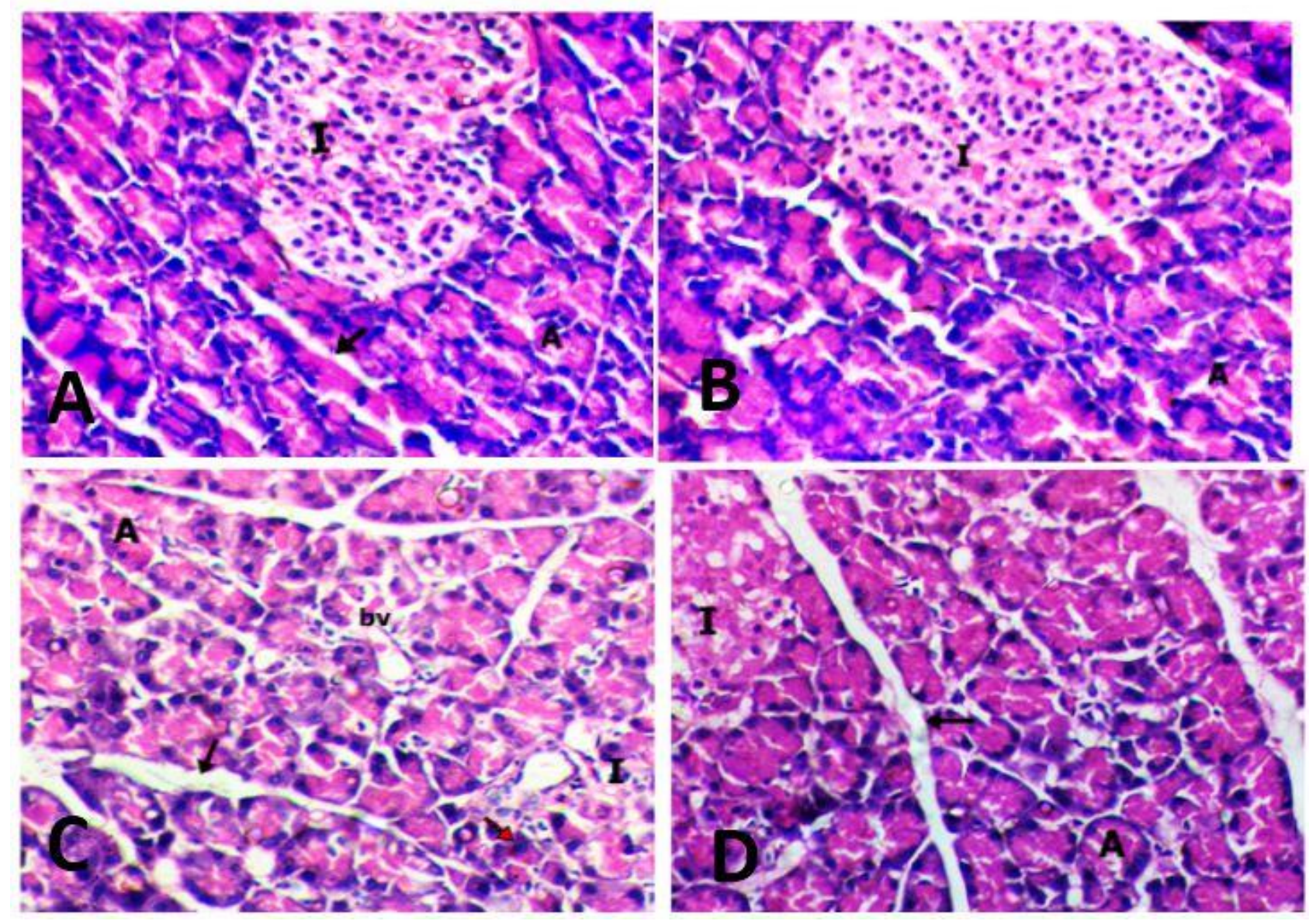

Figure 2: A photomicrograph of sections of rat pancreases of:

A, B: control group showing pancreatic lobules of closely packed acini (A) separated by thin interlobular septa (black arrow) and Islets of Langerhans (I) (H\&E X400).

C: chloropyrifos group showing degeneration of cells of acini (A) with widening of the interlobular spaces (black arrow) with blood vessels (bv) and infiltrated by inflammatory cells (red arrow). Cells of islet of Langerhans (I) is degenerated (H\&E X400).

D: follow up group showing improvement in the histopathological alterations no inflammatory reaction only mild degeneration of acinar cells (A) that has normal structure in form of as apical acidophilic cytoplasm and basal nuclei. Cells of islet of Langerhans (I) show mild degenerative change and still intercellular widening (black arrow) (H\&E X400). 

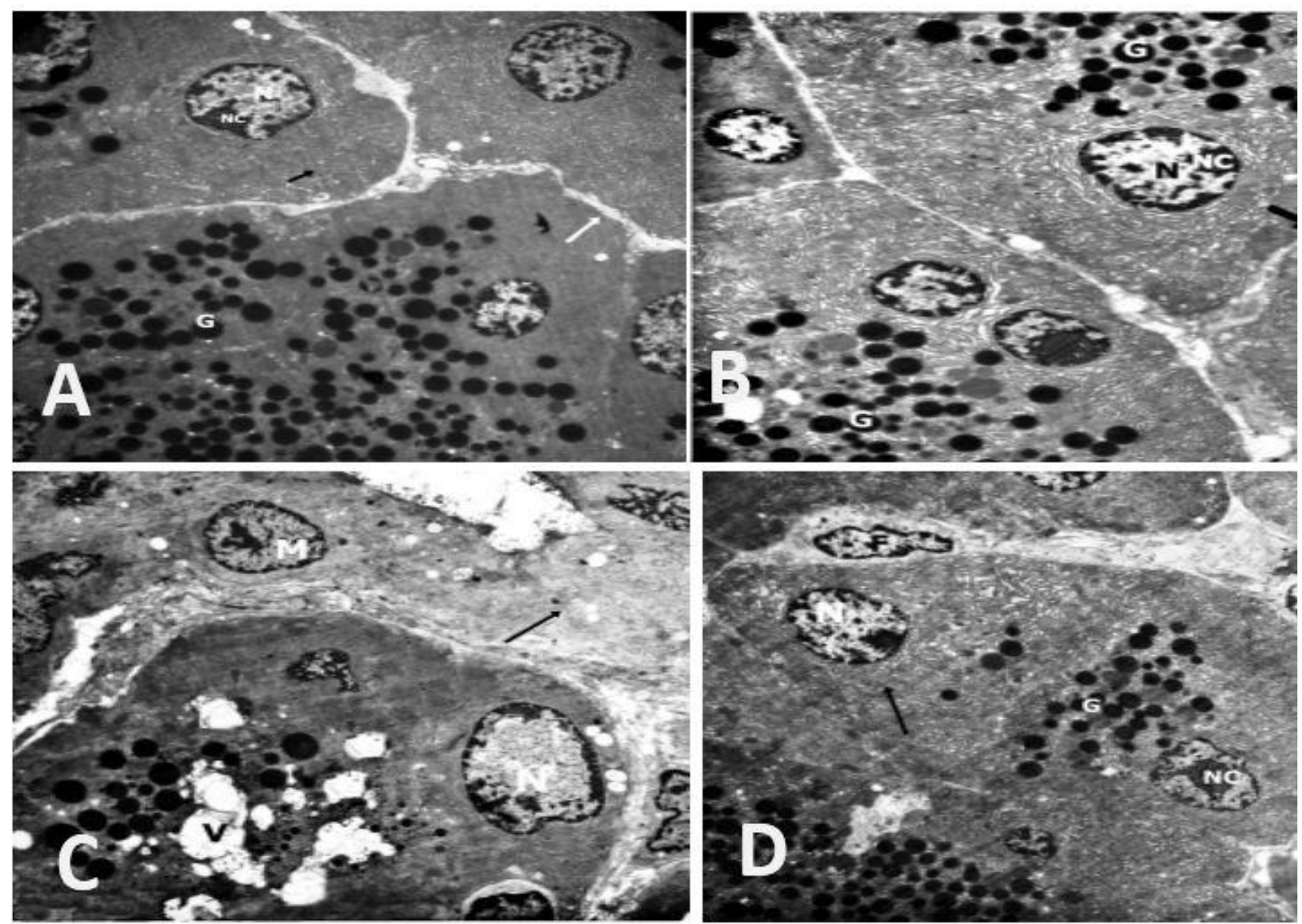

Figure 3: Ultra-structure of pancreatic acini of an ultrathin section of the pancreas obtained from:

A, B: control groups showing pyramidal acinar cells, they have rounded basal nuclei (N) containing prominent nucleoli (NC). The cytoplasmare packed with cisternae of rough endoplasmic reticulum (black arrow) and numerous secretory granules (G). The acini are surrounded by small amounts of connective tissue (white arrow) (TEM. Mic. Mag.x4000).

C: chloropyrifos group showing shrunken acinar cells with heterochromatic nuclei (N) and electron dense cytoplasm containing many vacuoles(V). The interstitial connective tissue (black arrow) appears with macrophage (M).

(TEM. Mic. Mag. x 4000).

D: follow up group showing acinar cell with rounded basal nucleus (N) containing prominent nucleoli (NC). The cytoplasm are packed with cisternae of rough endoplasmic reticulum (black arrow), with abundant secretory granules (G). The acini are surrounded by connective tissue with fibroblast (F). (TEM. Mic. Mag. x 4000).

\section{Discussion}

Chlorpyrifos is one of the most widely used OPs insecticides in agriculture and also as household insecticide. Due to its extensive use, residual quantities have been found in the ground, water sources, and food, giving rise to short-term or longterm exposures with consequent toxic effects (Poet et al., 2004; Richardson and Chambers 2005; Akande 2016).

The aim of this research was to assess toxic effect of chloropyrifos on pancrease, its ability to induce diabetes mellitus in adult male albino rats and evaluate whether this toxic effects are permanent or temporary.

In this research, chloropyrifos intake significantly reduced body weight. This observation was similar to results of other previous studies (Malik et al., 2004; Akhtar et al., 2009; Tripathi and Srivastava, 2010; Ambali et al., 2011; Mansour and Mossa, 2011; Heikal et al., 2012; Galakatu et al., 2012; Mossa \& Abbassy, 2012).
Chloropyrifos caused body weight loss as a result of its cholinergic action, oxidative stress and/or directly by increase breakdown of lipids and proteins (Goel et al., 2005; Mansour and Mossa, 2010; Mossa et al., 2011 and Heikal et al., 2012).

The pancreas contains two different types of cells, the exocrine cells, which secrete enzymes into gastrointestinal tract including amylase and lipase enzymes, and the endocrine cells, which secrete hormones into the blood involving insulin which plays an essential role in glucose homeostasis (Slack, 1995).

In this research, chloropyrifos administration caused highly significant increase in serum amylase and lipase levels.

These results are in line with that of Polat and Ogut (2018). They found significant increases in serum amylase and lipase enzymes in rats orally gavaged by chloropyrifos in a dose of $(0.3 \mathrm{mg} / \mathrm{kg} /$ day $)$ for 15 days. 
Pujari et al. (2016) found increased levels of amylase and lipase in OPs poisoning patients. A retrospective and prospective study was performed by Moussa et al., (2018) on acute OPs poisoning cases admitted to the Poison Control Center, Ain Shams University Hospitals in which $24 \%$ of cases had high amylase level, while $5 \%$ of cases had high lipase level. This was in agreement with previous study carried by Chaturvedi et al. (2014) where high amylase level was repeatedly observed in OPs poisoning.

Serum amylase and lipase can be utilized as a marker for estimating the degree of severity in OPs poisoning (Adhil and Sudharsan, 2015). However, in these case, it was found that serum amylase is helping in early identification of the patients at risk of developing complications and also, helping in early severity estimation. For these reasons, serum amylase may be considered as a useful marker in OPs poisoning (Panda and Nanda, 2014; Pujari et al., 2016; Salame and Wani, 2017; Moussa et al., 2018).

Acute pancreatitis is a recurrent adverse event in OPs poisoning. It is believed that acute pancreatitis occurred after OPs poisoning is caused by excess stimulation of pancreatic acinar cells as a result of excessive release of acetylcholine from pancreatic nerves (Singh et al., 2007).

These biochemical results were confirmed by histological examination of pancrease. There was degeneration of acini with widening of the interlobular spaces and infiltrated by inflammatory cells. Cells of islet of Langerhans were degenerated. These are compatible with that recorded by Kammon et al. (2011) who found degeneration and necrosis of glandular acini, and beta cells with proliferation of interlobular ducts in broilers after administration of chloropyrifos.

Degeneration of islet of Langerhans found in this work supported the alterations occurred in serum insulin and serum glucose. Chloropyrifos administration for 8 weeks caused an elevation in serum glucose with reduction in serum insulin.

Many researchers had a great focus on the ability of OPs to cause hyperglycemia (Rahimi and Abdollahi, 2007). Moreover, a positive correlation between chlorpyrifos exposures and occurrence of diabetes mellitus was reported (Montgomery et al., 2008).

These findings are in concurrent with that reported by Kalender et al., (2012); Krishna and Ramachandran (2009); Acker and Nogueira (2012); Orabi et al. (2013) and Hamza et al., (2014) where chlorpyrifos administration decreased serum insulin level and increased serum glucose level (hyperglycemia).

Pancreatic $\beta$-cells contain muscarinic receptors which play an important role in insulin production and release (D'Alessio et al., 2001; Duttaroy et al., 2004). By inhibiting AChE activity, chloropyrifos increases acetylcholine accumulation leading to more stimulation of its receptors and consequently downregulate these receptors (Van Koppen and Kaiser, 2003) resulting in reduction of insulin synthesis (Montgomery et al., 2008). Moreover, prolonged stimulation by acetylcholine may reduce $\beta$ - cell sensitivity to glucose (Gilon and Henquin, 2001). So, inhibiting AChE activity plays a role to some extent in OPs-induced hyperglycemia (Pourkahlili et al., 2009; Joshi and Rashini, 2010).

Hypersecretion of adrenaline is another mechanism explained hyperglycemia induced by OPs. Inhibition of AChE by OPs at neuroeffector sites in the adrenal medulla causes an increase in secretion of adrenaline (Gupta, 1974). Adrenaline elevates blood glucose by induction of gluconeogenesis and stimulating glycogenolysis in hepatocytes and myocyte cells (Gustavson et al., 2003; Rahimi and Abdollahi, 2007).

It was found that chloropyrifos impaired hepatic function with declining the capacity of liver to synthesize glycogen (Goel et al., 2006 Ambali et al., 2007; Ambali, 2009) and stimulating hepatic gluconeogenesis and glycogenolysis (Abdollahi et al., 2004).

Also, it enhances lipolysis causing increases in the levels of free fatty acid which have been suggested to have an inhibitory effect on the insulin signaling and inhibit glycogen synthesis (Itani et al., 2002).

Pournourmohammadi et al. (2007) suggested that chlorpyrifos can disrupts mitochondrial function of islets of Langerhans inducing a sort of insulin resistance that cannot control hyperglycemia.

In addition, oxidative stress has been shown to weaken role of insulin in glucose transport and glycogen synthesis through impairing the ability of insulin to stimulate glycogen synthase enzyme. So, the outcomes of these are lack of glycogen synthesis with high blood glucose (Dokken et al., 2008). This result was compatible with the result of this study where ingestion of chloropyrifos for 8 weeks increased serum level MDA and decreased serum level of GSH.

Normally, the human body fights the dangerous effects of free radicals by antioxidants. Oxidative stress happens when production of free radicals overrides the capacity of antioxidants. Oxidative stress has been implicated in many tissue and organ damage (Bhattacharya, 2015). One of mechanisms involved in the toxicity of OPs following sub chronic and chronic exposure, is lipid peroxidation by enhancing MDA production (Oncu et al., 2002; Akhgari et al., 2003; Sharma et al., 2005).

Malondialdehyde (MDA) is the most widely used indicator of lipid peroxidation in experimental studies (De Zwart et al., 1999). In addition, it is well known as mutagenic agent (Niedernhofer et al., 2003). While, GSH is an essential non-enzymatic antioxidant playing an important role in free radicals neutralization. As it is SH containing coenzyme, it has a role in xenobiotic detoxification (Dickinson and Forman, 2002).

Several previous studies showed an increase in lipid peroxidation after chloropyrifos administration (Gultekin et al., 2000; Tuzmen et al. 2008; Saulsbury et al., 2009; Ojha et al., 2011; Kalender et al., 2012; Uzun and Kalender, 2013; Kopjara et al., 2018; Owumi and Dim, 2019). 
Also, Baba et al. (2013) and Newairy and Abdou (2013) found increased levels of MDA with reduction in GSH levels in blood of rats exposed to chlorpyrifos. Moreover, chloroprifos was found to increase MDA and decrease GSH levels in brain and liver tissues causing oxidative damage in these tissues (Ahmed and Zaki, 2009; Verma et al., 2007; Chenikhar et al., 2018).

Calderón-Salinas et al. (2013) have proposed that oxidative stress participates in the pathogenesis, sequence, adverse effects and prognosis of diabetes mellitus.

Oxidative stress is known to activate redox sensitive kinases (RSKs) like Nuclear Factor kappa B (NFkB) and p38 Mitogen-Activated Protein Kinase (p38 MAPK) (Morgan and Liu, 2011; Son et al., 2011).

After activation of these redox sensitive kinases by oxidative stress, they impair tyrosine phosphorylation and cause serine phosphorylation of insulin receptor substrate-1 (IRS-1), negatively affecting insulin signaling with development of insulin resistance (Karin et al., 2005).

Chlorpyrifos is reported to affect expression of different genes in various tissues (Tang et al., 2018). Shrestha et al. (2018) found that chlorpyrifos impairs insulin signaling at the level of IRS-1as a result of activation of redox-sensitive kinases by oxidative stress enhanced by chlorpyrifos exposure. This might illustrate that chlorpyrifos is considered as a risk factor in the incidence of diabetes mellitus and insulin resistance state.

In the current study, 4 weeks of follow up without any treatment were associated with partial to complete improvement in the biochemical investigations and histological examination of tissues.

These are compatible with Padilla et al. (2005) who found that stoppage of chloropyrifos use for 3 months completely reversed all abnormal changes happened after chloropyrifos administration for periods of 6 or 12 months. Moreover, El-Tawil (2014) found that 3 weeks of recovery follow up caused improvement in all adverse effects induced by chloropyrifos.

\section{Conclusion \& Recommendations}

Chronic chloropyrifos exposure has toxic effect on pancrease and is considered as a risk factor for diabetes mellitus. Stoppage of exposure for a sufficient period can reverse these toxic effects. It is recommended to reduce utilization or even interrupt the use of insecticides including chloropyrifos and encourage more researches to find natural methods instead of these chemical insecticides.

\section{Conflict of interests}

No conflict of interests

\section{Acknowledgment}

A lot of thanks to Dr. Eman Al-Shahat (assistant professor of community medicine, Zagazig University) for her great help in statistical analysis.

\section{Reference}

Abdelaziz KB, El Makawy AI, Abd Elsalam AZ et al., (2010): Genotoxicity of Chlorpyrifos and the
Antimutagenic Role of Lettuce Leaves in Male Mice. Comunicata Scientiae, 1(2): 137145.

Abdollahi M, Ranjbar A, Shadnia S, et al., (2010): Pesticides and oxidative stress: a review. Med. Sci. Monit. 10: 141-147.

Abdollahi M, Donyavi M, Pournourmohammadi S, and et al., (2004): Hyperglycemia associated with increased hepatic glycogen phosphorylase and phosphoenolpyruvate carboxykinase activities in rats following subchronic exposure to malathion, Comp. Biochem. Physiol. C. Toxicol. Pharmacol. 137(4): 343-347.

Acker CI and Nogueira CW (2012): Chlorpyrifos acute exposure induces hyperglycemia and hyperlipidemia in rats. Chemosphere. 89: 602-608.

Adhil S and Sudharsan S (2015): Estimation of serum amylase and lipase levels in correlation with clinical outcome of OP poisoning. Int. J. Modn. Res. 3(10): 849-851.

Ahmed MM and Zaki NI (2009): Assessment the ameliorative effect of pomegranate and rutin on chlorpyrifos-ethyl-induced oxidative stress in rats, Nat. Sci. 7 (10): 49-61.

Akande MG, Shittu M, Uchendu C, et al., (2016): Taurine ameliorated thyroid function in rats co-administered with chlorpyrifos and lead. Vet. Res. Commun. 40(3-4):123-129.

Akhgari M, Abdollahi M, Kebryaeezadeh A, et al., (2003): Biochemical evidence for free radical induced lipid peroxidation as a mechanism for subchronic toxicity of malathion in blood and liver of rats. Hum. Exp. Toxicol. 22: 205-11.

Akhtar N, Srivastava MK and Raizada RB (2009): Assessment of Chlorpyrifos toxicity on certain organs in rat, Rattus norvegicus. J. Environ. Biol. 30(6): 1047-1053.

Al-Haj M, Nasser A and Anis A. (2005): Survey of pesticides used in Qat cultivation in Dhale and Yafe and their adverse effects. J. Nat. Appl. Sci. 9(1):103-110.

Al-Shinnawy MS, Hassan AR, Ismail DA, et al., (2014): The Potential Protective and Therapeutic Effects of Aloe Vera Juice on Malathion Induced Hepatotoxicity in Rabbits. The Egyptian J. Hosp. Med. 55: 146-158.

Ambali S, Akanbi D, Igbokwe N, et al., (2007): Evaluation of subchronic chlorpyrifos poisoning on haematological and serum biochemical changes in mice and protective effect of vitamin C. J. Toxicol. Sci. 32(2): 111-120.

Ambali SF (2009): Ameliorative effect of antioxidant vitamins $\mathrm{C}$ and $\mathrm{E}$ on neurotoxicological, haematological and biochemical changes induced by chronic chlorpyrifos exposure in Wistar rats. PhD Dissertation, Ahmadu Bello University, Zaria, Nigeria; pp: 356.

Ambali SF, Angani M, Adole AO, et al., (2011): Protective effect of vitamin $\mathrm{C}$ on biochemical alterations induced by subchronic coadministration of Chlorpyrifos and lead in 
Wistar rats. J. Environ. Anal. Toxicol. 1(3):108.

Baba NA, Raina R, Verma PK, et al., (2013): Toxic effects of fluoride and chlorpyrifos on antioxidant parameters in rats: protective effects of vitamins C and E, Fluoride. 46 (2): 73-79.

Bancroft D and Stevens A (1996): Theory and practice of Histological Techniques. $4^{\text {th }}$ edition, Churchill Livingstone Press, Edinburgh, London, Melbourne, New York. 99-112.

Beutler E, Duron O and Kelly BM (1963): Improved method for the determination of blood glutathione. J. Lab. Clin. Med. 61: 882-888.

Bhattacharya S (2015): Reactive Oxygen Species and Cellular Defense System. Free Radicals in Human Health and Disease. 17-29.

Calderón-Salinas JV, Muñoz-Reyes EG and QuintanarEscorza MA (2013): Estrés oxidativo y diabetes mellitus. REB. 32(2):53-66.

Carlsson A, Hallgren IB, Johansson H, et al., (2010): Concomitant Enzyme-Linked Immunosorbent Assay Measurements of Rat Insulin, Rat CPeptide, and Rat Proinsulin from Rat Pancreatic Islets: Effects of Prolonged Exposure to Different Glucose Concentrations. Endocrinol. 151(10): 5048 5052.

Cattani M, Cena K, Edwards J, et al., (2001): Potential dermal and inhalation exposure to chlorpyrifos in Australian pesticide workers. The Annals of Occup. Hyg. 45: 299-308.

Chaturvedi A, Dutta S, Sarkar S, et al., (2014): Prevalence of hyperamylasemia and acute pancreatitis in organophosphate poisonings. J. Dental and Med. Sci. 13(1):59-62.

Chenikhar H, Djabri B, Salmi A, et al., (2018): Hepatotoxicity induced by chlorpyrifos in 'Wistar' rats. Tunis. J. Plant Protec. 13 (si): 23-30.

Cox S, Niskar AS, Narayan KM, et al., (2007): Prevalence of self-reported diabetes and exposure to organochlorine pesticides among mexicanamericans?: hispanic health and nutrition examination survey, 1982-1984. Environ. Health Perspect. 115:1747-1752.

D’Alessio DA, Kieffer TJ, Taborsky GJ, et al., (2001): Activation of the parasympathetic nervous system is necessary for normal meal-induced insulin secretion in rhesus macaques. J. Clin. Endocr. Metab. 86: 1253-1259.

De Zwart LL, Meerman JHN, Commandeur JNM, et al., (1999): Biomarkers of free radical damage applications in experimental animals and in humans. Free Radic. Biol. Med. 26: 202-226.

Diab AA, Abd El-Aziz EA, Hendawy AA, et al., (2012): Possible Ameliorative Role of Propolis and Ginseng against Hepatotoxicity of Chlorpyrifos and Profenofos in Male Rats. J. Amer. Sci.8(8): 645-664.

Dickinson DA and Forman HJ (2002): Cellular glutathione and thiols metabolism. Biochem. Pharmacol. 64:1019-1026.
Dokken BB, Saengsirisuwan V, Kim JS, et al., (2008): Oxidative stress-induced insulin resistance in rat skeletal muscle: role of glycogen synthase kinase-3 . Am. J. Physiol. Endocrinol. Metab. 294: E615-21.

Duttaroy A, Zimliki CL, Gautam D, et al., (2004): Muscarinic stimulation of pancreatic insulin and glucagon release is abolished in M3 muscarinic acetylcholine receptor deficient mice. Diabe. 53: 1714-1720.

Elelaimy IA, Ibrahim HM, Abdel Ghaffar FR, et al., (2012): Evaluation of sub-chronic chlorpyrifos poisoning on immunological and biochemical changes in rats and protective effect of eugenol. J. App. Pharmacut. Sci. 2(6): 51-61.

El-Sheikh AA and Ibrahim HM (2017): The Propolis Effect on Chlorpyrifos Induced Thyroid Toxicity in Male Albino Rats. J. Med. Toxicol. Clin. Forensic. Med. 3:3.

El-Tawil MF (2014): Toxicological effects of shortterm feeding with chlorpyrifos and chlorpyrifos-methyl insecticides on adult albino rats. Middle East J. Agri. Res. 3(2): 208-220.

Environmental Protection Agency (EPA) (2000): Human health risk assessment. Chlorpyrifos. Washington, DC: U.S. Environmental Protection Agency. http://www.epa.gov/oppsrrd1/op/chlorpyrifos/ hedrra.

Food and Agriculture Organization (FAO) and World Health Organization (WHO) (2000): Pesticide residues in food. Toxicological evaluations joint meeting of the FAO panel of experts on pesticide residues in food and the environment and the WHO core assessment group Rome.

Galakatu SS, Joshi DV, Patel BJ, and et al., (2012): Toxicopathological Studies on induced Chlorpyrifos toxicity in Wistar rats (Rattus norvegicus). An international e J. 1(2).www.arkgroup.co.in

Gangemi S, Gofita E, Costa C, et al., (2016): Occupational and environmental exposure to pesticides and cytokine pathways in chronic diseases (Review). Inter. J. Mol. Med. 38: 1012-1020.

Garabrant DH, Aylward LL, Berent S, et al., (2009): Cholinesterase inhibition in chlorpyrifos workers: Characterization of biomarkers of exposure and response in relation to urinary TCPy. J. Exp. Sci. Environ. Epidemiol. 19 634-642.

Ghazala, Mahboob S, Ahmad L, et al., (2013): Fish cholinesterases as biomarkers of sublethal effects of organophosphorus and carbamates in tissues of Labeo Rohita. J. Biochem. Mol. Toxicol. 28:137-42.

Gilon P and Henquin JC (2001): Mechanisms and physiological significance of the cholinergic control of pancreatic beta-cell function. Endocr. Rev. 22: 565-604.

Glauret A and Lewis P (1998): Biological specimen preparation for transmission electron 
microscopy. Portland press, London, Vol.17, Retrieved from http://www.jstor.org/stable/j.ctt7ztxpn.

Goel A, Dani V and Dhawan DK (2005): Protective effects of zinc on lipid peroxidation, antioxidant enzymes and hepatic histoarchitecture in chlorpyrifos-induced toxicity. Chem. Biol. Interact. 156:131-140.

Goel A, Danni V and Dhawan DK (2006): Role of zinc in mitigating the toxic effects of chlorpyrifos on hematological alterations and electron microscopic observations in rat blood. BioMet. 19(5): 483-492.

Gultekin F, Ozturk M and Akdogan M (2000): The effect of organophosphate insecticide chlorpyrifos-ethyl on lipid peroxidation and antioxidant enzymes (in-vitro). Arch. ToxicoI. 74:533-538.

Gupta PK (1974): Malathion induced biochemical changes in rat, Acta Pharmacol. Toxicol. 35: $191-194$.

Gustavson SM, Chu CA, Nishizawa M, et al., (2003): Interaction of glucagon and epinephrine in the control of hepatic glucose production in the conscious dog. Amer. J. Phys. Endocr. Metab. 284: E695-E707.

Hamza RZ, Diab AA and Abd El-Aziz EA (2014): Hyperglycemic effect of Chlorpyrifos, Profenofos and possible ameliorative role of Propolis and ginseng. Sci. Agri. 5 (1): 9-14.

Heikal TM, Mossa ATH, Marci GI. et al., (2012): Cyromazine and Chlorpyrifos induced Renal Toxicity in Rats: The Ameliorating affects of Green tea Extract. Environ. Anal. Toxicol. 2(5): 146-152.

ILAR (Institute of Laboratory Animal Resources) (1996): Laboratory animal management: Rodents. Institute Of Laboratory Animal Resources, Commission on Life Sciences, National Research Council, National Academy Press, Washington, DC.

Itani SB, Ruderman NB, Schmieder F, et al., (2002): Lipid-induced insulin resistance in human muscle is associated with changes in diacylglycerol, protein kinase C, and IkappaBalpha. Diab. 51: 2005-2011.

Joshi AKR and Rajini PS (2010): Hyperglycemic and stressogenic effects of monocrotophos in rats: Evidence for the involvement of acetylcholinesterase inhibition. Exper. Toxicol. Pathol., Article in Press.

Joslin J (2009): Blood collection: Techniques in exotic small mammals. J. Exotic. Pet. Med. 18(2): 117-139.

Kalender Y, Kaya S, Durak D, et al., (2012): Protective effects of catechin and quercetin on antioxidant status, lipid peroxidation and testis-histoarchitecture induced by chlorpyrifos in male rats. Environ. Toxicol. Pharmacol. 33141-148.

Kammon AM, Brar RS, Sodhi S, et al., (2011): Chlorpyrifos chronic toxicity in broilers and effect of vitamin C. Open Vet. J. 1(1): 21-27.
Karami-Mohajeri S and Abdollahi M (2011): Toxic influence of organophosphate, carbamate, and organochlorine pesticides on cellular metabolism of lipids, proteins, and carbohydrates: A systematic review. Hum. Exp. Toxicol.30:1119-40.

Karin M and Gallagher E (2005): From JNK to pay dirt: Jun kinases, their biochemistry, physiology and clinical importance. Intern. Union Biochem Mol. Biol. Life. 7:283-95.

Kopjara N, Žunecb S, Mendašc G, et al., (2018): Evaluation of chlorpyrifos toxicity through a 28-day study: Cholinesterase activity, oxidative stress responses, parent compound/metabolite levels, and primary DNA damage in blood and brain tissue of adult male Wistar rats. Chemico-Biological Interactions, 279: 51-63.

Krishna H and Ramachandran AV (2009): Biochemical alterations induced by the acute exposure to combination of chlorpyrifos and lead in Wistar rats. Biol. Med. 1 (2): 1-6.

Kumar S, Fareedullah M, Sudhakar Y, et al., (2010): Current review on organophosphorus poisoning. Arch. Appl. Sci. Res. 2:199-215.

Kurahashi M and Inomata K (1988): Amylase secretion by parotid glands and pancreas of diabetic rats during feeding. Am. J. Physiol. 254, 878-882.

Lott JA, Patel ST, Sawhney AK, and et al., (1986): Assays of serum lipase: analytical and clinical considerations. Clin. Chem. 32:1290-1302.

Malik G, Dahiya JP and Gera S (2004): Biochemical studies on Chlorpyrifos toxicity in broiler chicken. Indian J. Animal Sci. 74(5): 473-476.

Mansour SA and Mossa AH (2010): Adverse effects of lactational exposure to chlorpyrifos in suckling rats. Hum. Exper. Toxicol. 29 (2):7792.

Mansour SA and Mossa AT (2011): Adverse effects of exposure to low doses of chlorpyrifos in lactating rats. Toxicol. Ind. Health. 27(3):21324.

Mansour SA (2010): Epidemiological studies of anticholinesterase pesticicide poisoning in Egypt. In: Satoh T, Gupta RC, editors. Anticholineseterase Pesticides: Metabolism, Neurotoxicity, and Epidemiology. John Wiley \&Sons, Inc. Hoboken, New Jersey, USA, p.379-401.

Mehta A, Verma RS and Srivastava N (2009): Chlorpyrifos-induced alterations in the levels of hydrogen peroxide nitrate and nitrite in rat brain and liver. Pesticide Biochem. Physiol. 94 (2-3): 55-59.

Mitra NK, Siong HH and Nadarajah VD (2008): Evaluation of neurotoxicity of repeated dermal application of chlorpyrifos on hippocampus of adult mice. Annals of Agri. Environ. Med. 15 (2): 211-216.

Montgomery MP, Kamel F, Saldana TM, et al., (2008): Incident diabetes and pesticide exposure among licensed pesticide applicators: 
Agricultural Health Study, 1993-2003. Amer.

J. Epidemiol. 67(10): 1235-1246.

Morgan MJ and Liu Z. (2011): Crosstalk of reactive oxygen species and NF- $\mathrm{KB}$ signaling. Cell Res. 21:103-15.

Mossa and Abbassy (2012): Adverse hematological and Biochemical effects of certain Formulated insecticide in male rats. Research Journal of Environment. Toxicol. 6: 160-168.

Mossa AH, Refaie AA and Ramadan A (2011): Effect of Exposure to Mixture of Four Organophosphate Insecticides at No Observed Adverse Effect Level Dose on Rat Liver: The Protective Role of Vitamin C. Res. J. Environ. Toxicol. 5: 323-335.

Moussa ME, Mohamed SA, Hilal MA, et al., (2018): The Role of APACHE II, SOFA, Serum amylase and Lipase in Assessment of Severity and Outcome of Acute Organophosphorus Poisoning. Ain Shams J. Fore. Med. Clin. Toxicol. 31: 41-50.

National Agricultural Statistics Services, NASS (2011): Agricultural Chemical Use Database. Pestmanagement.info. Available at: http://www.pestmanagement.info/nass/app_us age.cfm.

Newairy AA and Abdou HM (2013): Effect of propolis consumption on hepatotoxicity and brain damage in male rats exposed to chlorpyrifos, Afr. J. Biotechnol. 12 (33): 5232-5243.

Niedernhofer LJ, Daniels JS, Rouzer CA, and et al., (2003): Malondialdehyde, a product of lipid peroxidation, is mutagenic in human cells, $\mathrm{J}$. Biol. Chem. 278 (33): 31426-32133.

Ojha A, Yaduvanshi SK, and Srivastava N (2011): Effect of combined exposure of commonly used organophosphate pesticides on lipid peroxidation and antioxidant enzymes in rat tissues. Pesticide Biochem. Physiol. 99: 148156.

Oncu M, Gultekin F, Karaöz E, et al., (2002): Nephrotoxicity in rats induced by chlorpyrifos-ethyl and ameliorating effects of antioxidants. Human Exp. Toxicol. 21: 223230.

Orabi SH, Elbialy BE and Shawky SM (2013): Ameliorating and Hypoglycemic Effects of Zinc Against Acute Hepatotoxic Effect of Chlorpyrifos. Global Vet.10 (4): 439-446.

Owumi and Dim UJ. (2019): Manganese suppresses oxidative stress, inflammation and caspase-3 activation in rats exposed to chlorpyrifos Toxicol. Reports. 6:202-209.

Padilla S, Marshall RS, Hunter LD, et al., (2005): Neurochemical Effects of Chronic Dietary and Repeated High-Level Acute Exposure to Chlorpyrifos in Rats. Toxicol. Sci. 88(1): 161171.

Panda S and Nanda R (2014): Laboratory abnormalities in patients with organophosphorous poisoning. Indian Med. Gazette. 6-12.

Poet TS, Kousba AA, Dennison SL and Timchalk C (2004): Physiologically based pharmacokinetic/pharmodynamic model for the organophosporus pesticide diazinon. Neurotoxicol. 25: 1013-1030.

Polat M and Ogut S (2018): Effects of Application of Chlorpyrifos Ethyl and Rose Water on Rat Pancreas. Intern. Invention of Sci. J. 02(04): 109-116.

Pourkhalili N, Pournourmohammadi S, Rahimi F, et al., (2009): Comparative effects of calcium channel blockers, autonomic nervous system blockers, and free radical scavengers on diazinon-induced hyposecretion of insulin from isolated islets of Langerhans in rats. Arh. Hig. Rada. Toksikol. 60: 157-164.

Pournourmohammadi S, Farzami B, Ostad SN, et al., (2007): Effects of Malathion subchronic exposure on rat skeletal muscle glucose metabolism, Environ. Toxicol. Pharmacol. 19: $191-196$.

Pujari KN, Pore NE and Jadkar SP (2016): Serum Enzymes in Organophosphorous Poisoning. J. Med. Sci. Clin. Res. 4(6):10771-10778.

Raafat N, Abass MA and Salem HM (2012): Malathion exposure and insulin resistance among a group of farmers in Al-Sharkia governorate. Clin. Biochem. 45:1591-1595.

Rahimi R and Abdollahi M (2007): A review on the mechanisms involved in hyperglycaemia induced by organophosphorus pesticide. Pesticide Biochem. Physiol. 88: 115-121.

Randhawa M A, Anjum FM, Ahmed A, et al., (2007): Field incurred chlorpyrifos and 3, 5, 6trichloro-2-pyridinol residues in fresh and processed vegetables. Food Chem. 103:10161023.

Richardson JR and Chambers JE (2005): Effects of repeated oral postnatal exposure to chlorpyrifos on cholinergic neurochemistry in developing rats. Toxicol. Sci. 84(2):352-9.

Salame R and Wani A (2017): Study of serum amylase levels in organophosphate poisoning. Intern. J. Biomed. Adv. Res. 8(12): 450-454.

Sandhu MA, Saeed AA, Khilji MS, et al., (2013): Genotoxicity evaluation of chlorpyrifos: a gender related approach in regular toxicity testing. J. Toxicol. Sci. 38(2):237-244.

Saulsbury MD, Heyliger SO and Deadre JJ (2009): Chlorpyrifos induces oxidative stress in oligodendrocyte progenitor cells. Toxicol. 259: 1-9.

Sharma Y, Bashir S, Irshad M, et al., (2005): Dimethoate-induced effects on antioxidant status of liver and brain of rat following subchronic exposure. Toxicol. 215 (3):173181.

Shrestha S, Singh VK, Sarkar SK, et al., (2018): Effect of sub-toxic chlorpyrifos on redox sensitive kinases and insulin signaling in rat L6 myotubes. J. Diab. Metabo. Disor.17 :325332.

Shrestha S, Singh VK, Shanmugasundaram B, et al., (2016): The Effect of Chlorpyrifos, an Organophosphorus Pesticide, on Glucose 
Uptake in Whole Blood. J. Drug Metab. Toxicol. 7:211.

Singh S, Bhardwai U, Verma SK, et al., (2007): Hyperamylasemia and acute pancreatitis following acetylcholinesterase poisoning. Hum. Exp. Toxicol. 26(6):467-71.

Slack JM (1995). Developmental biology of the pancreas. Develop. 121(6):1569-80. 1.2

Soltaninejad K and Abdollahi M (2009): Current opinion on the science of organophosphate pesticides and toxic stress: a systematic review. Med. Sci. Monit.15:RA75-90.

Son Y, Cheong YK, Kim NH, et al., (2011): Mitogenactivated protein kinases and reactive oxygen species: how can ROS activate MAPK pathways? J. Signal Transduct. 2011:1-6.

Sun F, Wong SS, Li GC, et al., (2006): A preliminary assessment of consumer's exposure to pesticide residues in fisheries products. Chemosphere. 62: 674-680.

Tang G, Yao J, Zhang X, et al., (2018): Comparison of gene expression profiles in the aquatic midge (Chironomus tentans) larvae exposed to two major agricultural pesticides. Chemosphere. 194:745-54.

Tian Y, Ishikawa H, Yamaguchi T, et al., (2005): Teratogenicity and developmental toxicity of chlorpyrifos, Maternal exposure during organogenesis in mice. Reprod. Toxicol. 20(2):267-270.
Trinder P (1969): Determination of glucose in blood using glucose oxidase with an alternative oxygen acceptor. Ann. Clin. Biochem. 6:24-7.

Tripathi S and Srivastav AK (2010): Nephrotoxicity induced by long-term oral administration of different doses of Chlorpyrifos. Toxicol. Ind. Health. 26 (7): 439-47.

Tuzmen N, Candan N, Kaya E, et al., (2008): Biochemical effects of chlorpyrifos and deltamethrin on altered antioxidative defense mechanisms and lipid peroxidation in rat liver. Cell Biochem. Func. 26: 119-124.

Uzun FG and Kalender Y (2013): Chlorpyrifos induced hepatotoxic and hematologic changes in rats: The role of quercetin and catechin. Food and Chem. Toxicol. 55: 549-556.

Van Koppen CJ and Kaiser B (2003): Regulation of muscarinic acetylcholine receptor signaling. Pharmacol. Thera. 98: 197-220.

Verma RS, Mehta A and Srivastava N (2007): In vivo chlorpyrifos induced oxidative stress: attenuation by antioxidant vitamins, Pestic. Biochem. Phys. 88 (2): 191-196.

Yoshioka T, Kawada K, Shimada T, et al., (1979): Lipid peroxidation in maternal and cord blood and protective mechanism against activatedoxygen toxicity in the blood. Am. J. Obstet. Gynecol. 135: 372-376.

Zhao Q, Dourson M and Gadagbui B (2006): A review of the reference dose for chlorpyrifos. Regul. Toxicol. Pharmacol. 44(2):111-24.

\section{الملخص العربحى}

تقييم دور الكلوربيريفوس فى حدوث مرض السكري والآثار السامة على البنكرياس لدى الجرذان البيضاء البالفة وسواء هذه الآثار دائمة أم مؤقتة

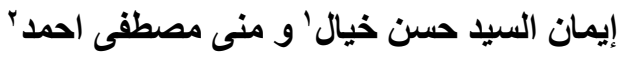

$$
\begin{aligned}
& \text { المقدمة: يعد الكلوربيريفوس أحد أكثر مبيدات الحشرات الفسفورية العضوية شيوعًا. أظهرت العديد من الدراسات وجود علاقة بين التعرض } \\
& \text { للمبيدات الحشرية وحدوث مرض السكري. كان المدف من البحث تقييم التأثير السام للكلوريوبيريفوس على البنكرياس ، وقدرته على حدوث مرض السكري }
\end{aligned}
$$

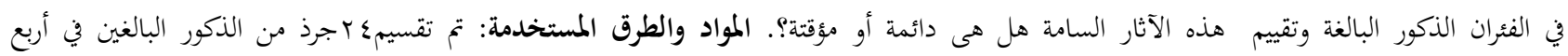

$$
\begin{aligned}
& \text { مجموعات. المجموعة الأولى: المجموعة الضابطة السالبة. المجموعة الثانية (المجموعة الضابطة الموجبة): تم إعطاء كل جرذ م, ـ مل من زئ زيت الذرة مرة واحدة في اليوم }
\end{aligned}
$$

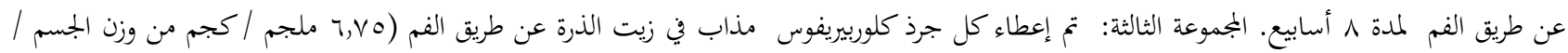

$$
\begin{aligned}
& \text { يوم) لمدة ^ أسابيع. المجموعة الرابعة: : تم إعطاء كل جرذ كلوربيريفوس بنفس جرعة المجموعة الثالثة لمدة م أسابيع ، ثم تُركت بدون علاج لمدة عـ أسابيع أخرى. }
\end{aligned}
$$

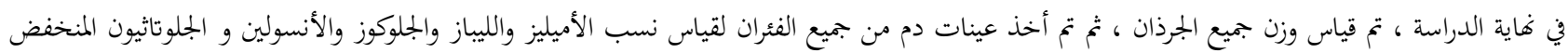

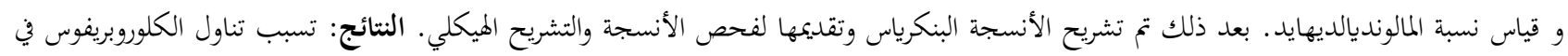

$$
\begin{aligned}
& \text { زيادات ملحوظة في نسب الأميليز في الدم ، والليباز ، والجلوكوز ، و المالونديالديهايد مع الخفاض ملحوظ في نسب التسب الأنسولين في الدم و الجلوتاثيون المنخفض. }
\end{aligned}
$$

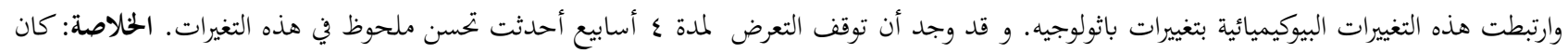

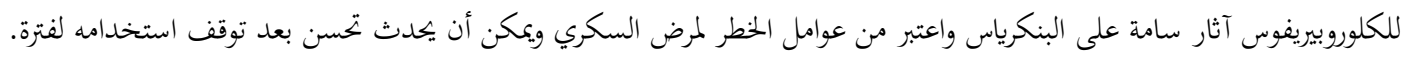

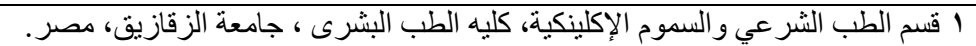

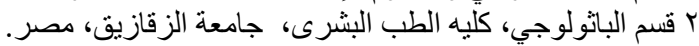

